\title{
テキスト情報による金融市場変動の要因分析
}

\section{Analysis of Financial Markets' Fluctuation by Textual Information}

\author{
和泉 潔 \\ 産業技術総合研究所 \& JST さきがけ \\ National Institute of Advanced Industrial Science and Technology \& PRESTO, JST \\ kiyoshi@ni.mints.ne.jp, http://kinba.sakura.ne.jp/ \\ 後藤 卓 \\ 三菱東京 UFJ 銀行 市場企画部 \\ The Bank of Tokyo-Mitsubishi UFJ, Ltd. \\ takashi_6_gotou@mufg.jp \\ 松井 藤五郎 \\ とうごろう機械学習研究所 \\ Tohgoroh Machine Learning Research Institute \\ TohgorohMatsui@tohgoroh.jp，http://とうごろう.jp
}

keywords: financial market, text-mining, time-series data, regression analysis.

\section{Summary}

In this study, we proposed a new text-mining methods for long-term market analysis. Using our method, we analyzed monthly price data of financial markets; Japanese government bond market, Japanese stock market, and the yen-dollar market. First we extracted feature vectors from monthly reports of Bank of Japan. Then, trends of each market were estimated by regression analysis using the feature vectors. As a result, determination coefficients were over $75 \%$, and market trends were explained well by the information that was extracted from textual data. We compared the predictive power of our method among the markets. As a result, the method could estimate JGB market best and the stock market is the second.

1.は じめ に

金融市場のトレーダー達は，市場に影響を及ぼす多樣 な情報を取捨選択し，現在の市場の状況を分析・予測し ている．しかし，送られてきた情報の全てを，現場の卜 レーダーが自分で目を通して市場分析に用いることは不 可能に近い，乥のため，いくつかの情報技術を市場分析 に適用する研究が行われ，一定の成果をあげてきた .

特に近年，テキスト情報による市場分析に関して，口 イターなどのオンラインの経済ニュースに対する市場の 反応を推測する研究もでてきた [Mittermayer 06, Seo 04, Ahmad 05, 高橋 07] .これらの研究は, 1 日以内や数日の 短期的な市場の反応を分析対象としており，より長期的 な市場動向の分析には用いられてこなかった .

本研究では, オンラインのテキスト情報から, 数年に わたる比較的長期の市場動向分析を支援するテキストマ イニング技術を新たに開発した。本技術を用いて実際に 経済市場分析を試み，実際の市場動向をどの程度説明し ているのかについて検証を行った .
2. テキストデータによる長期市場分析手法

今までテキストマイニングが長期的な市場分析にほと んど適用されなかった主な原因は次の 2 点である .

最初の問題は, ニュースや掲示板などの形式が多樣で 時間変化を抽出しにくいテキストを使用していたことで ある.この問題に関して, 本研究では長期分析に有効な テキストデータとして，日本銀行の金融経済月報を選ん だ、金融経済月報は，日本銀行が金融・経済情勢を分析 した資料であり，毎月半ばに，A4で15-20ページの分量 で公開されている*1.

この情報によって，日本銀行が，当面の経済動向をど う分析しているか対外的に明らかにしており，実際の金 融市場のトレーダーが多かれ少なかれ着目している共有 の重要テキスト情報である、金融経済月報が長期分析に 有効な理由は，ブログ等のほとんど決まった形式のない テキスト情報と異なり，解説内容の順番や段落構成等が ほぼ定式化されていて, 月ごとのテキスト内容の変化が 比較しやすいからである .

二番目の問題は, 市場分析用にテキストデータと時系 列データを関連づける手法がなかったことである . 二番

*1 テキストデータはhttp://www.boj.or.jp/theme/seisaku/ handan/gp/で毎月公開されている. 
目の問題に関して, 本研究ではテキストデータと時系列 データを関連づけるために，下記の 3 つのステップから なる新たなテキスト解析技術を提案する．

\section{$2 \cdot 1$ 共起関係に基づく主要単語の抽出と可視化}

最初に，各月のテキストデータに KeyGraph [大澤 06] を適用し，共起関係を解析した．具体的にはまず，日本 語形態素解析システムである Chasen $[\mathrm{ChaS}]$ による形態 素解析を行い, 出現頻度順に名詞・動詞・形容詞等を抽出 した . 次に , Jaccard 係数 $(=\mathrm{p}(\mathrm{A}$ and $\mathrm{B}) / \mathrm{p}(\mathrm{A}$ or $\mathrm{B}) ;$ た だし A,B は抽出した単語) を段落毎に適用し，段落毎に 同時に出現する単語と単語を繋ぎ，共起グラフを作成す る. 产の後, 単結合 (A,B 間のみの結合部分) を切断し， 結合による「島」を作成する．また光の後，各単語間の 共起度に基づき，上位順に「橋」を作成する．これらに よって, 各月のテキストデータから主要単語をノードと するネットワークを構築した .

\section{$2 \cdot 2$ 主成分分析による単語のグループ化}

KeyGraph で作成したネットワークに出現した単語の パターン (単語を月毎の出現状況に従いパターン分類した もの) に対し主成分分析を実施し，30 個の合成变数（主 成分) にまとめる.ここで，主成分の数が 30 個であっ たのは，1998 年から 2007 年までのデータを用いた主成 分分析で，累積寄与率が $60 \%$ を超えた主成分数が 30 で あつたからである . 各月の 30 個の主成分スコアを，分析 対象期間について時系列順に並べることによって，30 次 元の時系列データが作成される. これが分析対象期間の テキストデータの特徵の時間的変化を表していると考え る. 主成分分析の際には, 単語に関して品詞を区別せず に分析を実施する．ここで注意してほしいのは，ここま で市場データは全く用いず，純粋に単語の出現パターン のみの分析を行っていることである．つまり，ここまで の分析は, 債券市場や株式市場, 外国為替市場などの分 析対象となる市場の種類に依存せずに共通である .

\section{$2 \cdot 3$ 重回帰分析による市場データの動向分析}

最後に，各主成分スコアの毎月の動きから月次での市 場価格の動きを解析する . 具体的には , さきほどの 30 個 の主成分スコアの時系列データを説明変数として, 月次 の市場データを被説明変数とする重回帰分析を行う．得 られた回帰式に，月央に発表された最新のテキストデー タを入力すれば，約 2 週間後の月末の市場価格を推定 (外 捙予測)できる .

\section{3. 金融経済月報のテキストマイニング}

上述の手法を用いて，日本国債市場 (金利)・株式市場 (日経平均株価) ・外国為替市場 (円ドルレート) の月次変 動を分析した . 1998 年 1 月から 2007 年 12 月までの 10
年間 (120ヶ月) の金融経済月報のテキストと各市場デー タ (月末終值) をサンプルデータとした .

\section{$3 \cdot 1$ 金融経済月報による月次市場分析}

最初に，KeyGraph アルゴリズムと主成分分析を用い て, 30 次元の特徵量を金融経済月報のテキストデータか ら抽出した . 抽出された主成分には大きく分けて $2 つ の$ タイプがあった . 一つは市場の動きに関する特徽量であ る.例えば， 1 番目の主成分は,「横ばい」「圏内」「緩や か」といった動きを表す単語から構成されていた，他に も， 5 番目の主成分は,「上昇」「頭打ち」「軟化」といっ た単語の寄与が高かった，もう一つのタイプは，経済の ファンダメンタルズに関する特徽量である．例えば， 2 番 目の主成分は「リスク」「国債」「利回り」といった金利 に関する単語から構成されていた．他にも，3 番目の主 成分は,「需要」「改善」「生産」といった企業活動に関す る単語の寄与が高かった .

次に, これらの 30 次元の特徵量の時系列データを用い て , 各市場データの回帰分析を行った . 回帰分析の際に, AIC 基準を用いたステップワイズ選択により，説明変数 の絞り込みを行った. 日本国債の 1 年物，2 年物， 5 年 物，10 年物の金利について，23-25 個の説明変数による 回帰式を得ることができた . 日経平均については 18 個， 円ドルレートに関しては 13 個の説明変数が選択された . 決定係数 $R^{2}$ をみると, サンプルデータについて十分な 説明力を持つことがわかつた . $R^{2}=75.24 \%$ (国債 1 年物)， $78.47 \%$ (国債 2 年物)，76.76\%(国債 5 年物)，74.65\%(国 債 10 年物)，85.67\%(日経平均)，76.38\%(円ドルレート).

\section{$3 \cdot 2$ 外挿予測力の市場間比較}

前節で得られた 1998 年 1 月から 2007 年 12 月までの 過去 10 年間の訓練データを用いた回帰式に，2008 年 1 月から 12 月までのテキストデータを入力して, 各金融 市場における外挿予測テストを行った。

図 1a-dに，代表的な市場について，推定されたパスと 実際のパスを示す . 外挿期間における推定パスと実際の パスを比較すると, 日本国債 2 年物 (図 1a) と 5 年物 (図 1b) がトレンドの方向性 (上昇と下降) および価格の全体 的な水準が一致しており，最も精度の高い外插予測を行っ ていた . 次に日本国債 1 年物と日経平均株価 (図 1c) が， 価格の全体的な水準に乘離がみられたものの, トレンド の方向性が一致していた . 日本国債 10 年物は，価格の 全体的な水準が合っていたものの, 価格の変化量か実際 の動きよりも小さく推定された . 最後に, 円ドルレート (図 1d) に関しては, 市場トレンドの方向性と価格の全体 的な水準ともにうまく推定することができなかった .

上述の比較結果を確かめるために，実際に提案テキス トマイニング手法が使われる場面と同樣に, 直近のデー タまでを訓練データとして毎月新しいデータを追加して 新たに分析を更新した場合の外插予測力の比較を行った . 
(a) 日本国債 2 年物
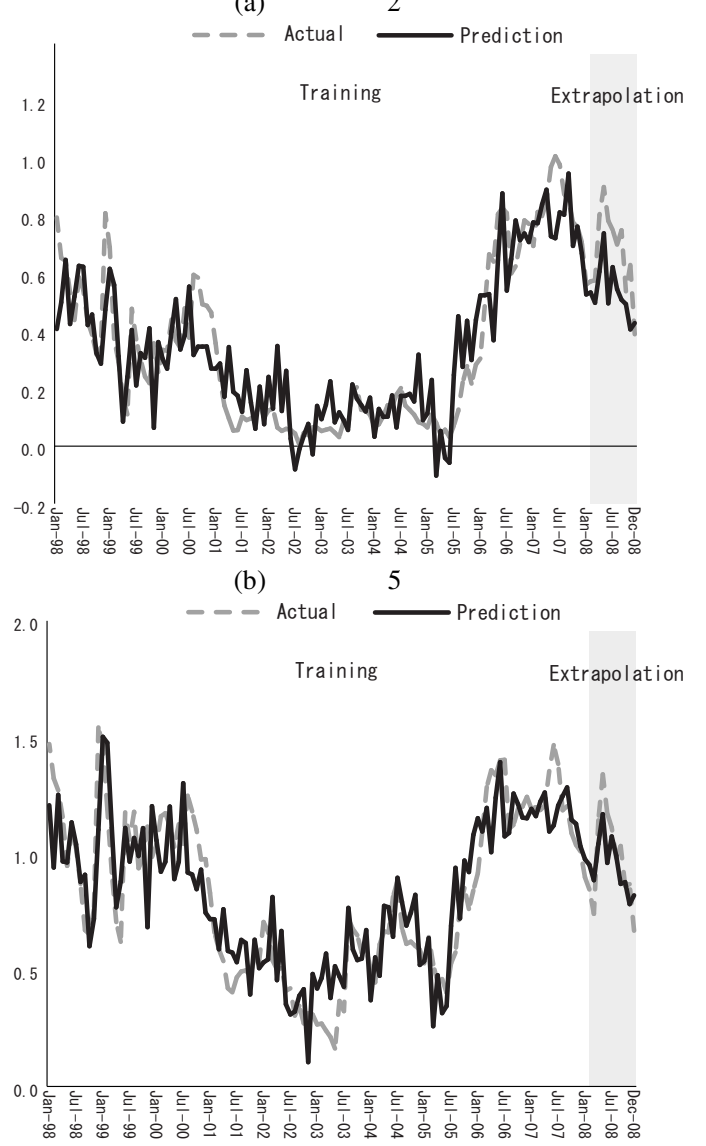

(c) 日経平均株価

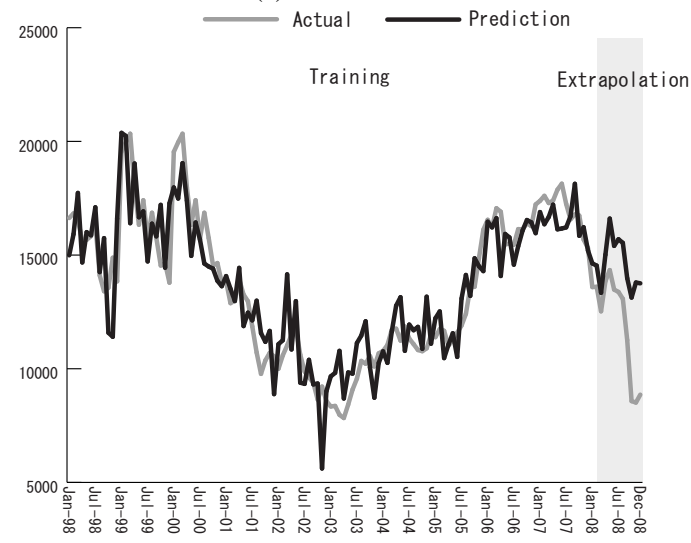

(d) 円ドルレート

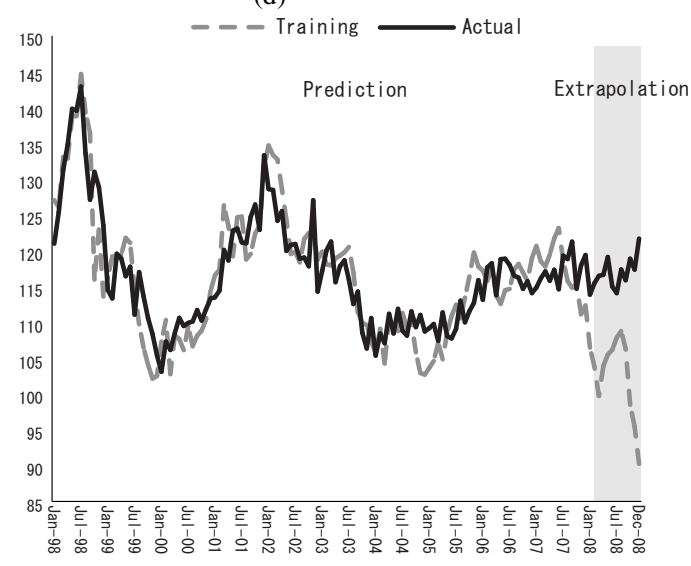

図 1 各市場トレンドの推定.訓練期間: 1998 年 1 月〜2007 年 12 月，外捙期間: 2008 年 1 月 12 月.
まず最初に 1998 年 1 月から 2007 年 9 月までのテキス トデータと市場データを訓練データとして回帰式を推定 し，弚の式に 2007 年 10 月のテキストデータを入力して， 2007 年 10 月末の市場価格を推定した . 次に 2007 年 10 月のテキストデータと市場データを訓練データに追加し て新たに回帰式を推定し，光の式に 2007 年 11 月のテキ ストデータを入力して，2007年 11 月末の市場価格を推 定した . 同樣に毎月のデータを追加して回帰式を逐次的 に更新しながら，月末の市場価格を外挿予測するテスト を，2008 年 10 月の市場価格の外挿予測まで繰り返した .

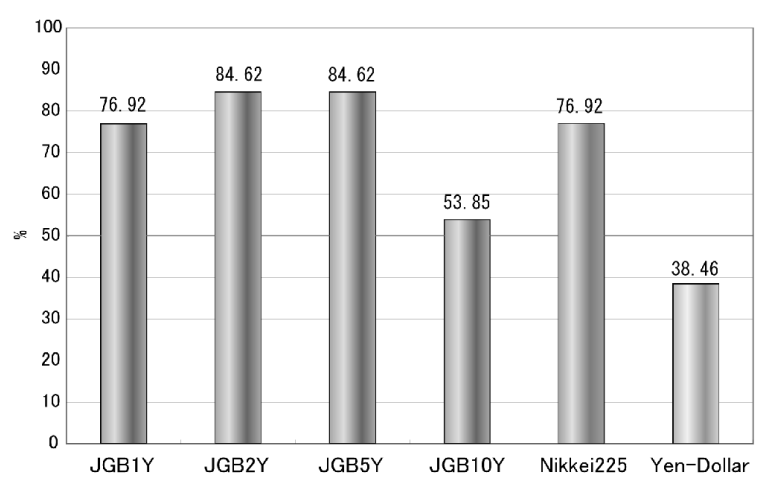

図 2 各市場の逐次的な外挿予測における市場トレンドの正答率比 較. 2007 年 10 月〜2008 年 10 月までの各月末価格に関して 外挿予測を行った。

图 2 は, 各市場において, 上記の手続きで逐次的な外 挿予測を行った各月の推定值のトレンドが，実際の市場 トレンドと比較して何\%の期間で正解していたかを示す

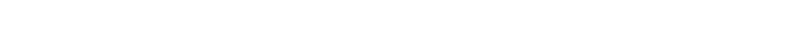
昇トレンド/下降トレンドにあるかの一致を調べた .この 結果より，図 1 で調べた外挿予測の精度比較結果と同樣 に，国債 2 年物 (JGB2Y) ・ 国債 5 年物 (JGB5Y) > 国債 1 年物 (JGB1Y) ・ 日経平均株価 (Nikkei225) > 国債 10 年

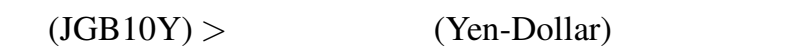
予測力の精度が高かったことがわかる．

\section{$3 \cdot 3$ 市場変動の要因分析}

豊かな背景情報を含むテキストデータを用いることに よって、テキスト情報て解説されている特定の経済状況 と，金融市場の変動の関連性を見つけ出すことができる． 日経平均株価について，さきほどの 2008 年の外挿期間 について, 本手法により変動が大きくなると推定された 月の, 変化量が大きかった主成分について調べた (図 3).

兴の結果，2008 年 4 月の上昇局面では，第 3 主成分 (PC3) と第 4 主成分 (PC4) に関連する単語が, 光の月の 日銀月報での出現パターンが前月から変化していたこと が分かった．表 1 に示すように，第 3 主成分は「需要」 「改善」「生産」といった企業活動に関する単語の寄与が 高く，第 4 主成分は「設備」「国内」「輸出」といった貿 

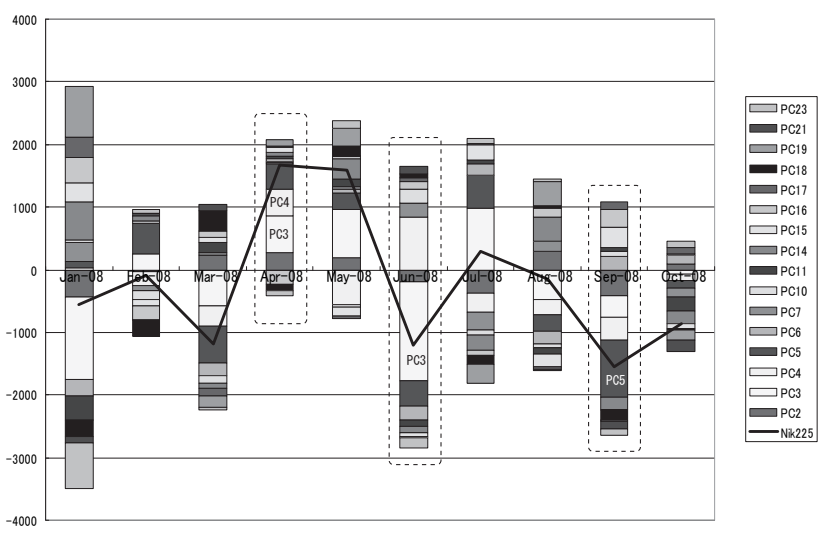

図 3 日経平均株価の外挿期間での変動要因 . 実線 (Nik225) はテキ スト分析での推定值 . 棒グラフの各項目 (PC2-PC23) は, 各 主成分の前月からの変化量に回帰係数をかけた値 .

易収支に関する単語の寄与が高かった .このように 2008 年 4 月の日経平均株価の上昇は, 経済的な基礎要因に関 係していることが示された .

2008 年 6 月と 9 月の下降局面についても主成分の変化 を調べた結果 , 同じ下降局面でも要因が異なると示唆さ れた.6月の下落に最も関連した主成分は，企業活動に 関する第 3 主成分 (PC3) であった．乥れに対し，9 月は 「上昇」「頭打ち」「軟化」といった市況やトレンドに関す る単語の寄与が高い, 第 5 主成分 (PC5) が最も関係性が 強かった .このことから，6月の下降は経済の基礎的要 因の変化を反映したものであったが，9月の下降は株式 相場の状況自体が変動要因になっていたと推測される .

表 12008 年 4,6,9 月の変動要因となった主成分. 各主成分で負荷 量の絶対值が上位 10 個のキーワードを示す．

\begin{tabular}{lrlrlr}
\hline \multicolumn{2}{c}{ 第 3 主成分 } & \multicolumn{2}{c}{ 第 4 主成分 } & \multicolumn{2}{c}{ 第 5 主成分 } \\
\hline 背景 & 0.655 & 設備 & 0.468 & 足許 & -0.458 \\
伴う & 0.494 & 国内 & -0.432 & 上昇 & -0.436 \\
需要 & 0.452 & 低迷 & 0.421 & 実体 & -0.401 \\
改善 & -0.424 & 輸出 & -0.411 & 年末 & -0.394 \\
生産 & -0.421 & 歯止め & 0.36 & 頭打ち & -0.394 \\
鈍化 & -0.404 & 掛かる & 0.36 & 先行き & -0.381 \\
軟調 & -0.394 & 総合 & 0.36 & 厳しい & 0.374 \\
国債 & -0.394 & 対策 & 0.36 & 間 & -0.363 \\
利回り & -0.394 & ベース & 0.358 & 軟化 & -0.355 \\
格差 & -0.394 & 踏まえる & 0.354 & ベ一ス & 0.352 \\
\hline
\end{tabular}

市場変動は樣々な要因か影響している可能性があり，ど れが主な原因となっているかを現場で特定することは難 しいことが多い，本手法によって，日銀や多くの市場関 係者がどの要因に着目しているのか， これからどの要因 に気をつけるべきかを絞り込むことができ，金融の現場 の意志決定支援になることが期待できる .

\section{4. ま と め}

本研究では, テキストデータによる長期的な市場分析 の新手法を提案した . 月次の日本国債市場・株式市場・外
国為替市場データの分析を行った結果，国債 2 年物・国 債 5 年物 $>$ 国債 1 年物・日経平均株価 > 国債 10 年物 > 円ドルレートの順で，外挿予測力の精度が高かった .さ らに, 日経平均株価について 2008 年 4 月の上昇局面と 6 月と 9 月の下降局面の変動要因を, 主成分の值の変化 より分析した．弚の結果，4 月と 6 月の変動は経済の基 礎的要因と関連しており，9月の下落は市況自体の要因 か関連したとの示唆を得た .

今後は本手法をマーケットリポートやブログ等のより 条件の厳しい情報に適用を試みる予定である．また市場シ ミュレーションとの統合により動的な市場分析を目指す．

謝辞

本研究の一部は, 科学研究費補助金 特定領域研究「情 報爆発 IT 基盤」の助成を受けています．

\section{$\diamond$ 参 考 文 献 $\diamond$}

[Ahmad 05] Ahmad, K., Gillam, L., and Cheng, D.: Textual and Quantitative Analysis: Towards a new, e-mediated Social Science, in Proc. of the 1st International Conference on e-Social Science (2005)

[ChaS] ChaSen ホームページ: http://chasen.naist.jp/ hiki/ChaSen/

[Mittermayer 06] Mittermayer, M. A. and Knolmayer, G.: Text Mining Systems for Market Response to News: A Survey, Working paper (2006)

[Seo 04] Seo, Y.-W., Giampapa, J. A., and Sycara, K.: Financial News Analysis for Intelligent Portfolio Management, Technical Report CMU-RI-TR-04-04, Carnegie Mellon University (2004)

[高橋 07] 高橋悟, 高橋 大志, 津田 和彦: 株式市場におけるヘッド ラインニュースの効果についての研究, ファイナンス学会第 15 回大会, pp. 373-383 (2007)

[大澤 06] 大澤 幸生 : チャンス発見のデータ分析一モデル化+可 視化+コミュニケーションーシナリオ創発, 東京電機大学出版局 (2006)

〔担当委員 : 松村 真宏〕

2009 年 8 月 25 日 受理 


\section{著 者 紹介}

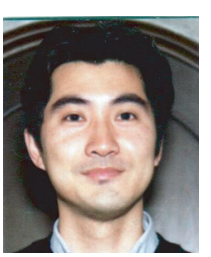

\section{和泉 潔(正会員)}

1993 年東京大学教養学部基礎科学科第二卒業. 1998 年同 大学院博士課程修了. 博士 (学術). 同年より, 電子技術総 合研究所 (現 産業技術総合研究所) 勤務. マルチェージェ ントシミュレーション,特に社会シミュレーションに興枺が ある. 情報処理学会, 電子情報通信学会, 電気学会各会員,

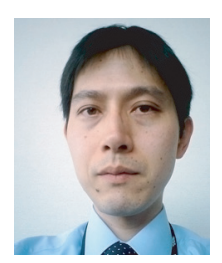

\section{後藤 卓}

1997 年 名古屋大学工学部情報工学科卒業 . 同年株式会社 東海銀行 (現株式会社三菱東京 UFJ 銀行) 入社, 2008 年 より現職 . 1998 年より ALM 及び債券運用業務に従事し 2001 年から 2007 年までプロップ・トレーディング業務に 従事.うち 2002 年から 2007 年までロンドン勤務. 帰国 後, 円貨資金証券部を経て現在に至る。

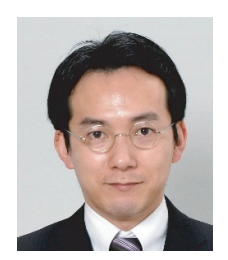

松井 藤五郎(正会員)

1997 年 名古屋工業大学知能情報システム学科卒業 . 2003 年同大学院工学研究科博士後期課程電気情報工学専攻修 了. 2003-2009年東京理科大学理工学部経営工学科助教. 2009 年より現職. 機械学習および強化学習に関する研究 に従事し，現在は機械学習やデータ・マイニングをファイ ナンスの分野へ応用する研究に取り組む。情報処理学会, ACM , AAAI 各会員. 